\title{
Body and Mind in the Trobriand Islands
}

\section{GUNTER SENFT}

\begin{abstract}
This article discusses how the Trobriand Islanders speak about body and mind. It addresses the following questions: do the linguistic data fit into theories about lexical universals of body-part terminology? Can we make inferences about the Trobrianders' conceptualization of psychological and physical states on the basis of these data? If a Trobriand Islander sees these idioms as external manifestations of inner states, then can we interpret them as a kind of ethnopsychological theory about the body and its role for emotions, knowledge, thought, memory, and so on? Can these idioms be understood as representation of Trobriand ethnopsychological theory?
\end{abstract}

The Truth of the statement touched me in the pit of the stomach (you know that's the spot where emotion gets home on a man)....

Joseph Conrad, Chance

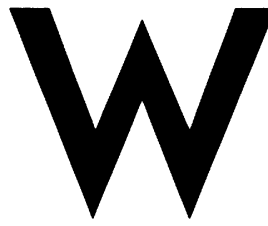

hen it comes to the question of "body and mind" in Kilivila (the Austronesian language of the Trobriand Islanders), I assume that everyone familiar with Bronislaw Malinowski's ethnographic masterpieces will remember the following rather famous passage from The Argomauts of the Western Pacific:

The mind, nanola, by which term intelligence, power of discrimination, capacity for learning magical formulae and all forms of non-manual skill are described, as well as moral qualities, resides somewhere in the larynx. The natives will always point to the organs of speech, where the nanola resides. The man who cannot speak through any defect of his organs, is identified in name (tonagowa) and in treatment with all those mentally deficient. The memory, however, the store of formulae and traditions learned by heart, resides deeper, in the belly. A man will be said to have a good nanola, when he can acquire many formulae, but though they enter through the larynx, naturally, as he learns them, repeating word for word, he has to stow them away in a bigger and more

GUNTER SENFT is a senior research fellow in the Cognitive Anthropology Research Group at the Max Planck Institute for Psycholinguistics in Nijmegen, The Netherlands.

Ethos 26(1):73-104. Copyright (C) 1998, American Anthropological Association. 
commodious receptacle; they sink down right to the bottom of his abdomen. I made the discovery of this anatomical truth, while collecting war magic from Kanukubusi.... I paid him well for the few formulae he gave me, and inquired at the end of our first session, whether he had any more magic to produce. With pride he struck his belly several times and answered: "Plenty more lies there!" I at once checked his statement by an independent informant and learned that everybody carries his magic in his abdomen. . . . the main idea, that magic rests in the belly, is clear and definite. . . The force of magic, crystallized in the magical formulae, is carried by men of the present generation in their bodies. ... The force of magic does not reside in the things; it resides within man and can escape only through his voice. [1922:408-409]

From this quotation we learn at least the following: first, the Trobriand Islanders have a concept that comes close to what we call "the mind." According to Malinowski's informants this concept is located "somewhere in the larynx." And second, in connection with the memorizing of magical formulae, the Trobriand Islanders also have a concept that comes close to what we call "memory." According to Malinowski, the islanders believe that these formulae are stored in the belly.

Given Malinowski's observations we may infer that for the Trobriand Islanders of Papua New Guinea the concepts of body and mind seem to be as strongly interrelated as they are for European philosophers. ${ }^{1}$

\section{SPEAKING ABOUT BODY AND MIND IN KIUVILA}

When I started my field research on the Trobriand Islands some ten years ago, the above quoted observation by the master of Trobriand ethnography came into my mind when I elicited Kilivila body-part terms. Having returned from the field after the first 15 months of my research, I checked the results of these elicitation sessions with my corpus of documented and transcribed speech data for the compilation of the Kilivila dictionary. Getting all the data together I realized that Kilivila not only meticulously differentiates the external and internal parts of the human body, but it also grammaticalizes terms that refer to body parts into locatives; moreover, a number of idioms (most often consisting of a verbal expression together with either a body-part term or the general terms for "body" and "mind") are used to refer to a person's feelings, inner states, and mental activities (Senft 1986).

In this article I will present the relevant data and discuss how the Trobriand Islanders speak about body and mind. I will particularly address the following questions:

- Do the Kilivila data fit into theories and findings about lexical universals of body-part terminology?

- Can we make inferences about the Trobrianders' conceptualization of psychological and physical states on the basis of the linguistic data? 
- If a Trobriand Islander sees these idioms as external manifestations of inner states, can we then interpret them as a kind of ethnophysiological theory about the body and its role in emotion, knowledge, thought, memory, and so on? Can these idioms be understood as representations of Trobriand ethnopsychological theory and, if so, what can we say about the body locations encoded in these idioms, that is, does the mind really reside somewhere in the larynx-from the Trobriand Islander's point of view?

\section{Kilivila Body-Part Terms and Lexical Universals of Body-Part Terminology}

Most of the Kilivila body-part terms consist of a noun that obligatorily takes a possessive pronominal suffix indicating an intimate degree of possession. There is a fourfold series of possessive pronouns in Kilivila, which is partly realized in free possessive-pronominal-pronoun forms and partly realized in possessive-pronominal affixes. I refer to the series of pronouns that are suffixed to most of the body-part terms as "possessive pronouns IV" and abbreviate this expression as "PPIV" (for details see Senft 1986:47-54). I will illustrate this paradigm with the Kilivila noun for body, vovo-PPIV:

$\begin{array}{lll}\text { 1.Ps.Sg. } & \text { vovo-gu } & \text { my body } \\ \text { 2.Ps.Sg. } & \text { vovo-m } & \text { your body } \\ \text { 3.Ps.Sg. } & \text { vovo-la } & \text { her or his body } \\ \text { Dual incl. } & \text { vovo-da } & \text { our bodies } \\ \text { Dual excl. } & \text { vovo-ma } & \text { our bodies } \\ \text { 1.Ps.Pl.incl. } & \text { vovo-dasi } & \text { our bodies } \\ \text { 1.Ps.Pl.excl. } & \text { vovo-masi } & \text { our bodies } \\ \text { 2.Ps.Pl. } & \text { vovo-mi } & \text { your bodies } \\ \text { 3.Ps.Pl. } & \text { vovo-si } & \text { their bodies }\end{array}$

Besides the term for body, "vovo-PP IV," I have so far documented 99 bodypart terms for Kilivila. These terms are listed in appendix $\mathrm{A}$.

In "Lexical Universals of Body-Part Terminology" Elaine Andersen emphasizes that within this lexical domain we find "a high degree of orderliness and predictability across languages which reflects the basic modes of cognition and perception which human beings share" (1978:338); Andersen also points out that it is especially this domain "for which we can assume a common perceptual reality-human bodies are structurally the same, no matter what the culture" (1978:346). ${ }^{2}$

If we compare her findings with the Kilivila body-part terms presented in appendix $\Lambda$, we realize that the Kilivila data confirm all her universal postulates. 
The Kilivila terms constitute a hierarchical organization that can be described as partonomic, that is, as consisting of "part of" relationships ( $\Lambda$ ndersen 1978:347). With respect to its hierarchical structure and organization (which is indicated in the order of the body-part terms in appendix $\Lambda$ ), the Kilivila system represents a body-part partonomy with six notional levels in Andersen's sense (1978:348). ${ }^{3}$

The Kilivila data also confirm that the lexical domain of external body parts encodes visually perceptible properties of spatial location and orientation (Andersen 1978:335). When categorizing the parts of the body, Kilivila-like most languages-makes use of the three planes of reference our species is provided with. As Bowden nicely illustrates, "the first plane is symmetrical and runs down the centre of the body. . . The second plane is assymetrical and runs across the centre of the body . . the third plane . . . is also assymetrical and runs along the base of the feet" (1992:88-89). The first plane separates left and right, the second plane separates front and back, and the third plane is the horizontal plane at ground level with which we distinguish objects above ground level from objects below ground level. ${ }^{4}$ The Kilivila body-part terms and the terms that are grammaticalized as locatives confirm that in this language verticality is also regarded as an especially salient orientation (see Andersen 1978:345). Moreover, the Kilivila data reveal what $\Lambda$ dersen (1978:362) calls "salience of the upper body": there are many more terms in Kilivila that refer to the upper part of the body than terms that refer to the lower part.

Finally, the Kilivila data also confirm that, with respect to the formation of body-part categories and the classification of parts of the body, visually perceptible properties like "the shape features round and ... long are especially salient" and play a major role (Andersen 1978:345, 335, emphasis in original).

\section{Speaking Idiomatically about the Body and the Mind in Kilivila}

In Kilivila, as in many other (and probably all) languages, ${ }^{5}$ we find a number of body-part terms in idiomatic usage. Generally speaking, these idiomatic expressions form a complex predication, the meaning of which more often than not cannot be deduced from the meaning of its components. The expressions are used to refer to what we would call descriptions of certain states of mind, feelings, emotions, and so on. The possessed body-part term often translates as the grammatical subject of the predication. To give just two illustrative examples:

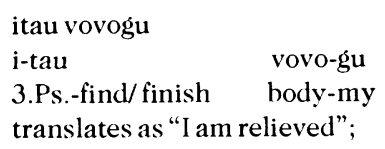


dabagu gidageda

daba-gu gidageda

head-my pain

translates as "I have a headache."

The list of body-part terms in appendix A contains some idiomatic expressions such as matala nunu-PP IV, nipple (the eye/tip of the breast), and matala kusi-PP IV, glans penis (eye/tip of the penis), where one body part is used as a kind of metaphor for a part of another body part.

For the purposes pursued here I would like to define idiom as broadly and generally as possible as "a form of expression, construction, phrase, etc. peculiar to a language" (McElhanon 1975:111, 103, 105, 108; see also Hockett 1958-173-175; Pawley 1986). In these idioms we observe a combination of some body-part terms with a predication that most often consists of a verbal expression in the third-person singular or plural. The body-part term can but need not be the subject of this predication. Some of these verbal expressions are only produced in the documented idiomatic usage; thus I could not discover any meaning for the verbal expression when it was isolated from the particular body-part term. These expressions may be compared to what David Tuggy (n.d.) calls "scarecrow nouns": as we all know, a "scarecrow" is not a special crow, but a thing that scares crows. Speakers of English know the processes of word formation and the etymology necessary to understand such an expression. Unfortunately, no comparable information is available with respect to these Kilivila idioms, and thus in some cases it is impossible to give the literal translation of the predications. In appendix B I present the examples of body-part terms in idiomatic usage as they are documented in my data. In what follows I will answer the questions raised above on the basis of these data.

Can We Make Inferences about the Trobrianders'Conceptualization of Psychological and PhysicaVPhysiological States on the Basis of the Linguistic Data? The idiomatic expressions the Trobriand Islanders use when speaking about body and mind are based on only seven body-part terms (according to my extensive corpus of Kilivila speech data and the results of my lexicographic research). Besides the general terms for "body" and "mind," Kilivila speakers use the term for "belly" and three terms that refer to the "head" and to parts of it, namely to the "eye," to the "ear," and to the "mouth," in constructing these idioms. Thus, we have the nouns

- vovo-PPIV (body) with 11 idiomatic usages,

- daba-PP IV (head) with 6 idiomatic usages,

- mata-PP IV (eye) with 1 idiomatic usage,

- tega-PP IV (ear) with 1 idiomatic usage,

- vado-PP IV (mouth) with 1 idiomatic usage,

- lopo-PP IV (belly) with 2 idiomatic usages, and

- nano-PP IV (mind) with 38 idiomatic usages. 
On the basis of this list we can infer that the nouns that refer to "eye," to "ear," to "mouth," and to "belly" seem to play only a minor role with respect to the idiomatic usage of body-part terms, whereas the nouns that refer to the "head" in particular and to the "body" and "mind" in general are most prominent for the construction of these idioms in Kilivila.

The idioms presented in appendix B can be subcategorized as follows:

1. expressions that constitute body-part term compounds to refer to parts of the body: for example, matala nunum (your nipple) (3.2); see also 3.3 , with the noun mata-PP IV (eye) ${ }^{7}$

2. expressions that refer to a person's feelings and inner states: for example, ibisibasi vokuva vovogu (I am racked with pains) (1.1); see also 1.2.-1.10, with the noun vovo-PP IV (body); 2.3 , with the noun daba-PP IV (head); 4.1, with the noun tega-PP IV (ear); 6.2, with the noun lopo-PP IV (belly); 2, 3, 7, 8, 10-13, 15, 16, 22, 29-31, 33, 34, and 37, with the noun nano-PP IV (mind)

3. expressions that refer to mental activities or to behavior patterns that affect mental activities: for example, ininaki lopogu (I keep it quiet/to myself (6.1), with the noun lopo-PP IV (belly); see also 1, $4-7,9,14,17-21,24,26,27,32,35$, and 36 , with the noun "nano-PP IV (mind)

4. expressions that refer to a person's physical behavior: for example, vovogu yuviyavi (I am feverish) (1.11), with the noun vovo-PP IV (body); see also 2.1, 2.6, with the noun daba-PP IV (head); 3.1, with the noun mata-PP IV (eye)

5. expressions that are used to characterize a person: for example, mtona dabasi tommota (this is a wise person) (2.2); see also 2.4, 2.5 , with the noun daba-PP IV (head); 5.1 , with the noun vado-PP IV (mouth); 23, 25, 38, with the noun nano-PP IV (mind)

Given these subcategories, we can now try to answer the question whether these idioms constitute a basis for making inferences about the Trobrianders' conceptualization of psychological and physical/physiological states.

The subcategory of idioms that refer to a person's physical behavior has a clear biological base. With all human beings we observe a "hot body" (1.11), and especially a "hot (fore-)head" (2.6), when they are "feverish." If we have a headache we all feel some pain in our heads (2.1). It is also a general observation that persons who are "fainting" have "distorted eyes" just before they become "unconscious" (3.1). With this subcategory of idioms the Trobriand Islanders refer in much the same way to symptoms that indicate a person's physical behavior from a medical point of view, much as medical laymen in Europe, in Australia, and in the United States (and probably all over the world) usually do. 
With respect to other physical/physiological and psychological states, we observe that Kilivila speakers use idioms based on the terms for "body," "head," "ear," "belly," and "mind" to express some of their feelings and inner states. To refer to mental activities and behavior patterns that may affect these activities the Trobriand Islanders use idioms based on the terms for "belly" and "mind." Finally, to characterize a person the speakers of Kilivila use idioms that consist of the terms for "head, mouth," and "mind."

If we compare this with the idioms we find in Indo-European languages, almost all these notions are quite familiar-even at first sight. In English and German, for example, we find many idioms that we usually label as "conventional metaphors" (Keesing n.d.:23) or as "body metaphors" (Haviland 1987:6), which use exactly the same body-part terms as Kilivila, though with different predications, to express quite similar concepts. Thus we speak of "a good head for business," a "useless mouth," a "mastermind" if we want to characterize persons. With respect to idiomatic reference to mental activities, we say that we "keep something in mind" and that we "cannot stomach something." Finally, when referring to physical and psychological states, we say that we are "absent-minded" or "light-headed," that we "put something out of someone's head," that we are "head over heels in love with linguistics and anthropology," that we "have a person's ear," that we "keep body and soul together," that "someone gives us a pain in the belly" or that we have "a gut feeling." That these analogies exist in completely unrelated languages is nothing new. In his paper "Body Image Idioms in Irianese and Papua New Guinean Languages," McElhanon (1977:6-7, see also 1975:140-141), for example, emphasizes that in Old and Middle English body-image idioms we can find astonishing parallels with respect to the concepts that underlie the body metaphors he found in Selepet, a Papuan language of the Huon Peninsula. In the same vein, Keesing argues that metaphors "based on body parts differ much less than we might expect from language to language" (n.d.:18), and Haviland points out that "should it turn out ... that systems of body metaphor are neither widely divergent nor exotic, that they are in some describable sense natu$r a l$, then we are freed of the need to posit exotic beliefs and anatomical theories to explain them" (1987:15, emphasis in original).

Thus, if we accept that we can take body-part metaphors in Indo-European languages as a basis for making inferences about our conceptualization of psychological and physical states-with all necessary caution, of course-then we can also use the Kilivila idioms in their own right for exactly the same purpose. This implies that, if we have no other evidence, we will not attribute any form of "deeper salience" to the Trobriand Islanders' conventional body-part metaphors than we do to our own (Keesing n.d.:39). The questions that remain to be answered, however, are how culture-specific is the information encoded in these Kilivila idioms? and are 
these idioms "constitutive of experience" and do they "guide and constrain thought" (Keesing n.d.:40) with respect to the Trobriand Islanders, and if so, how? 8

To answer these questions we will look at the Kilivila body-part idioms in more detail. With respect to the idioms that are used to characterize a person, we can note the following:
mtona dabasi tommota
this is a wise person
literally: this is the people's head

The Trobriand Islanders' society is highly socially stratified (Malinowski 1968[1929], 1935; Senft 1987; Weiner 1976, 1988). To achieve and to maintain a position of status requires a number of mental abilities such as being a good rhetorician, and being able to convince people and guide them to make wise decisions. Thus, a wise person is also one of the leading heads in Trobriand society. This is something that also holds for many other societies and ethnic groups in the Pacific (and it is claimed to hold for the leading persons in politics, economy, science, and so on, in our societies, too-at least in theory).
pe'ula dabala a confident person literally: (it is) strong, his/her head

In the Trobriands as elsewhere confident persons do not take things too easily, and they certainly keep confidential things to themselves. This may sometimes require some determination, a "strong head," especially in societies that are as open as the Trobrianders' society.

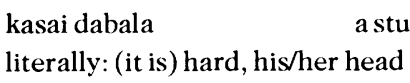

Teachers in our societies quite often complain that with some pupils they just cannot get anything into their heads. It goes without saying that this complaint does not refer to their brighter students. The Trobrianders, too, refer to a stupid person as a person with a "hard" head.

(5.1) iudu vadola

s/he cannot keep her/his mouth shut; a hypocrite

I cannot offer a literal translation of this idiom.

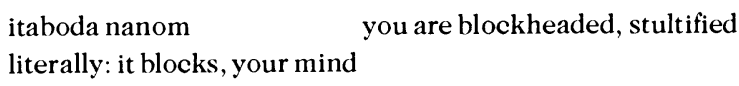

The English term blockheaded comes quite close to this Kilivila concept; for the Trobrianders, however, it is not the head but the mind that is taken as being blocked. 
If we agree that a person who is obsessed with an idea has somehow cut out of his mind all other considerations, then we should not have too many difficulties understanding the concept behind this idiom.

(38) mtona gala nona he is senseless

literally: this man (has) no mind

This idiom is self-evident.

To summarize, among the body-part idioms Kilivila uses to characterize a person, we do not find any culture-specific information encoded that needs much explanation in order to understand the concepts that the idioms refer to and are based on.

With respect to the idiomatic expressions that refer to a person's feelings and inner states we observe the following: first of all, I cannot comment on five expressions here, because I cannot give the literal translation of the predications that go with the body-part terms. The relevant expressions are

(1.3) ikai'iki vovogu

(1.4) ikaikai vovogu

(1.6) imwana vovogu

(2) ikaikai nanosi

(22) isugwa nanogu

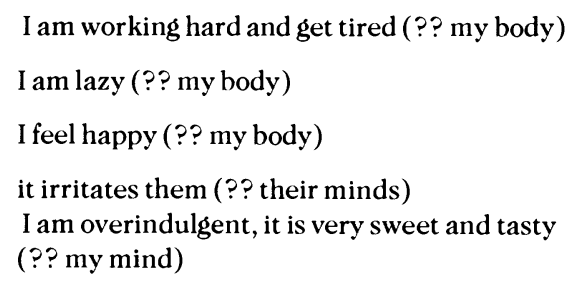

Moreover, although the literal translations of the following two idioms are available, I just cannot explain them on the basis of the literal meaning of the predication. These idioms are
itau vovogu
I am relieved
literally: it found/it finishes, my body
itoki vovogu
I feel overburdened
literally: it stands/attends, my body

I have no idea on what concepts these two idioms are based.

The meaning of the following eight expressions, however, is self-evident if we look at their literal translations. The concepts expressed here are similar to the familiar concepts we express in our Western cultures and languages-at least to my mind!:
(1.5) imama vovogu
literally: it gets
I feel weak
bikalisau nanom
(a) it will charm you
(b) you will steal something
literally:
(a) it will be outstanding for your mind
(b) you will steal something-(it is on) your mind

The second meaning here can be interpreted as an intensification of the first meaning: if something is on one's mind, one may try everything to get 
hold of it-and the Trobriand Islanders then even take some illegal action into consideration. But if we remember that we also have idioms like "to steal one's heart," this illegal act may not be as severe as it may look at first sight!

$$
\text { ikavisi nanosi they are fascinated }
$$

literally: they are fascinated, their minds

(11) imwamwasila nanogu I am in good humor

literally: it is in a good mood, my mind

imwau nanogu I am sad

literally: it feels grief (?), my mind

$$
\text { ipani nanosi it confuses them }
$$

literally: it confuses their minds

(16) ipolu nanom it makes you jealous

literally: it is jealous (worries, is boiling), your mind

nanogu gaga
literally: my mind (is) bad.

The following expressions need some comment, I assume, to really understand them:

(1.1) ibisibasi vokuva vovogu I am racked with pain literally: it entwines my body entirely

As my informants told me, this idiom encodes the concept of a person in pain who twists his or her body in such a way that she or he seems to have his or her body parts entwined with each other.
(1.2) iǵwegwesi vovogu (a) I feel tired (staying in a foreign village;
I feel homesick)
(b) I am fed up with something.

literally: it feels tired / is fed up with something, my body

On the one hand, this idiom has been semantically narrowed from expressing a general feeling of tiredness to expressing a feeling of homesickness. The idiom comes close to one of the connotations of the English expression "I am tired of this place." On the other hand, the idiom has been semantically broadened to expressing a general feeling of being fed up with something.

(1.9) itutu vovogu I am excited
literally: it hammers, my body

This idiom encodes the concept that a person is so excited that her or his whole body is throbbing and vibrating with emotion; the throbs and vibrations pulsate like rhythmical hammer strikes.

$$
\begin{aligned}
& \text { itutuvakau vovogu I am experienced } \\
& \text { literally: it hammers (again[?]), my body }
\end{aligned}
$$


With the predication of this idiom we find the same verb stem as with the predication of the previously quoted idiom, modified only by the morpheme "vakau," which can be interpreted as a kind of intensifier. Here the basic concept seems to be that someone feels a certain excitement; however, this excitement has been experienced before. This familiarity with a (bodily) experienced phenomenon is then generalized into the meaning "to be experienced."
ibulumse'u dabala literally: it smokes, her or his head

This idiom is very picturesque; indeed, if one's head is clouded by smoke, it is easy to get confused and disoriented.
kasai tegala
she/he is feigning deafness, being angry
literally: (it is) hard/difficult, her/his ear

The basic concept underlying this idiom is an idea that is very familiar to human ethologists: if we try or pretend to close one of our channels for sensory input, we are either angry about, or afraid of, something.

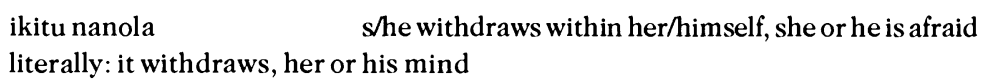

s/he withdraws within her/himself, she or he is afraid

This idiom again summarizes a phenomenon no human ethologist or psychiatrist could describe better. Persons who withdraw their minds from their social environment so that they "withdraw within themselves" are usually afraid of something.

(10) bimanum nanomi you won't be angry literally: they will be gentle, your minds

The basic concept of this idiom is quite evident: if your mind is in a gentle mood, then it is hard to get angry.
(13)
gala bimau nanom don't worry
literally: it will not be heavy, your mind

Again, if your mind is not busy trying to solve burdensome and difficult problems, if you are not "heavy-hearted"(!), then you do not worry.
itutuvakau nanosi
they are very much impressed
literally: it hammers (and hammers?) their minds

The concept behind this idiom-which incidentally shows the same predication as the expression (1.9) quoted and described above-is that you feel throbbing vibrations (this time not in your whole body, but) in your mind as if they were hammering inside you. If your mind reacts to something or someonelike this, you certainly must be deeply impressed by this thing or person. 
If we slightly modify the literal translation so that it reads "it causes (caused) me to make up my mind (to do something)," then the concept underlying this idiom is evident.
ivakavili nanom
it turns your mind against something/someone
literally: it turns something and continues doing something (with it), your mind

Here, too, the basic concept of the idiom is not too difficult to describe: if you have been thinking something over for a long time without having come to a decision, then more often than not this unsatisfying situation will finally turn you against the problem you have been thinking over so unsuccessfully. You become fed up with it.
iyelu nanogu
I long for it, I am inspired with it
literally: it remembers, my mind

This idiom refers to the fact that something we remember again and again is something we long for or are inspired with.
iyogagi nanola
it upsets her/him
literally: it spoils, her/his mind

The basic concept behind this idiom can be described as follows: if we are in a good mood and something happens that spoils the atmosphere, then it is quite understandable that we get upset.

So far, all the idioms cited are easy to understand for speakers of IndoEuropean languages. There is nothing whatsoever that makes it necessary to posit anything as culture specific as the underlying concept for these body-part idioms. The attentive reader, however, may have noticed that one expression is missing in this section-and here, indeed, we hit upon a phenomenon that has to be described by referring back to ideas that may be culture specific for the Trobriand Islanders' society. This idiom refers back to the phenomenon mentioned by Malinowski (1922:408-409) in that famous passage of "Argonauts of the Western Pacific" with which I started this article. The idiom runs
ikapisi lopogu
s/he is sorry/mourns/feels pity with someone literally: it feels pity, her/his belly (!)

It seems that we have to deal with the Trobriand "belly" once more. Why do the Trobrianders say that they feel sorry for someone, that they mourn, and that they feel pity for someone with their belly? Is it a "gut feeling" for them? How should we try to describe and explain this idiom?

Before I try to answer these questions, however, I will first look at the Kilivila idioms that refer to mental activities or to behavior patterns that affect them, to finish this part of the article. With respect to these idiomatic expressions we observe the following: again, I cannot comment on two expressions here, because I cannot give the literal translations of the predications that go with the Kilivila term for "mind." These expressions are: 
(21) isivili nanodasi

(35) iyokwaisi nanodasi it changes our minds it converts us, it turns us away from someone (?? our minds)

The meaning of the following ten expressions, however, is self-evident if we look at the literal translation of the idioms. The concepts expressed here are again similar to concepts we express in our Western cultures and languages:
(1) ida'ila nanom
(a) it changes your mind
literally: it changes / remembers, your mind
(4) ikanta'ila nanodasi it convinces/persuades us literally: it convinces/persuades our minds
(5) ikamituli nanogu I admit/reveal/report literally: it admits/reveals/reports, my mind
(7) ikavisi nanosi they are fascinated (by an idea, a thought) literally: they are fascinated, their minds
(9) iluvai nanogu I remember literally: it remembers, my mind
(14) imimi nanogu (a) I dream (see also 20 below)
(b) I make magic
literally: it dreams / makes magic, my mind

Ilere the second meaning needs just a few comments: magic still plays an important role in the everyday life of the Trobriand Islanders. With some forms of magic the magician has to put him or herself into a kind of trance, where s/he "dreams" that the expected result of the magic has already come true.

(19) isinapu nanogu I tell fibs, I swindle

literally: it cheats/tricks/sets a trap for someone, my mind

(20) isipolu nanogu I dream, I have a nightmare

literally: it dreams (things that worry me), my mind (see also 14 . a above)

(24) itagwala nanogu I agree

literally: it agrees/accepts, my mind

(26) itamwau nanogu I forgot it, it slipped my memory

literally: it loses (it), my mind

The following expressions need some comment again, I assume, to really understand them:

(6) ikatotila nanom literally: it promises (it), your mind

The idea behind this idiom is that if your mind "promises" you or, if you will, itself to do something, then you are really determined to do it. 
The basic concept here is that whenever your mind is trying hard to solve a given problem, you are certainly thinking it over.

(18) isim nanogu I am conscious of something

literally: it hurts/stings, my mind

I assume that this idiom once meant something like "to be painfully aware of something"; the idiom, however, must have lost its more negative connotation over the course of time. The simile "something that stings one's mind" has been weakened and now only refers to the fact that "someone is aware of something."

$$
\begin{aligned}
& \text { itavilisi nanosi they reconsider it } \\
& \text { literally: they turn (it), their minds }
\end{aligned}
$$

This idiom is based on the concept that whenever you look at something from different angles and perspectives (and this is where the aspect of the mentally "turning" comes in), you reconsider it.

$$
\begin{aligned}
& \text { iweya nanola s/he remembers something } \\
& \text { literally: it brings something, her/his mind } \\
& \text { it is floating, her/his mind }
\end{aligned}
$$

The concept underlying this idiom is the observation that when your thoughts are "floating" more or less aimlessly, quite often something comes suddenly to your mind and you remember it.

(36) bala nanogu I will have an idea

literally: it will go (away from here), my mind

This idiom reveals that the Trobriand Islanders seem to have some different ideas about how someone will have, or get, an idea about something. While English and German speakers usually think, and verbally state, that ideas come (in)to their minds, the Kilivila speakers state verbally that their minds will go away from where they are now-most probably to find the idea they want to have. If we modify the literal translation in this direction, glossing "bala nanogu" as "my mind will go away_and look for an idea," then the basic concept underlying this idiom becomes somewhat more familiar to speakers of Indo-European languages. The Trobriand Islanders emphasize the action that has to be taken to get an idea!

Again we can summarize that all the Kilivila idioms cited are easy to understand for speakers of Indo-European languages and that it is not necessary to posit anything culture specific as the underlying concept for these body-part metaphors. The attentive reader, however, may have noticed once more that one expression is missing again in this section, and, once more, it is an expression that refers to the Trobriand Islander's "belly." The idiom runs 


\section{(6.1) ininaki lopogu I keep it quiet I keep it to myself \\ literally: it keeps something for itself, my belly}

With this idiom we once again find the belly as a place for storing information. This seems to be exactly the same concept as the one Malinowski hit upon when he worked with his informant Kanukubusi collecting war magic.

At this stage of our analysis we can summarize as follows: with the exception of the two idioms that consist of a predication and the Kilivila noun for "belly," we have not found any evidence that the Trobriand Islanders have an indigenous ethnopsychological and ethnophysiological theory about "body and mind" and the roles they play with respect to feelings, inner states, emotions, mental activities, knowledge, thought, memory, and so on. On the contrary, a closer look at these idioms reveals that we can observe many parallels and analogies between the concepts that underlie the Kilivila idioms on the one hand and the concepts that underlie, for example, the comparable English idiomatic expressions on the other. If these idioms and the concepts they are based on guide and constrain the Trobriand Islanders' thought, then it seems plausible to assume that they do this in exactly the same manner as the idioms in English and German. ${ }^{9}$ Therefore, if extreme relativists argue that "idioms, metaphors and other extensions, represent the crystallization of what is unique in the thought of a particular culture," as Haviland (1987:1) points out, or that "Idiomaticity . . . reflects the speaker's perception of reality, and with regard to body image idioms, its definition reflects cultural norms" as McElhanon (1982:44) put it, then the vast majority of the Kilivila idioms presented here can be taken as constituting a "particularly potent challenge" (Haviland 1987:1) to this position. The Kilivila idioms point out the possibility of a "universal" organization of our conception of "human nature," of the nature of our bodies, and of our inner states and feelings.

The Belly and the Larynx-Aspects of the Trobriand Islanders' Ethnophysiological-Psychological Theory of Body and Mind?! Although the vast majority of the data presented here support the notion of a more "universal" organization of our conception of "human nature," we have to discuss the few Kilivila body-part idioms that seem to be more culture specific.

The first of these idioms is

(6.2) ikapisi lopogu s/he is sorry/mourns/feels pity with someone literally: it feels pity, her/his belly

In connection with this idiom we raised the following questions: Why do the Trobrianders think that they feel sorry for someone, that they mourn, and that they feel pity for someone with their belly? Is it a "gut feeling" for them? Or how should we try to describe and explain this idiom? 
Indeed, at least at first sight this idiom-which locates feelings of pity and mourning in the belly-may strike us as a rather culture-specific notion. It seems, however, that at least at the beginning of our century the notion that the "pit of the stomach ... [is] . . the spot where emotion gets home on a man. .." was quite familiar for Europeans as well-according to Conrad's (1988[1914]:29) observation and statement to be found in his novel Chance. Moreover, I assume we have all experienced some more or less emotionally laden situations where we noticed and felt some strange reactions in our bellies and stomachs. (And here the question as to whether or not we have a "nervous stomach" in general does not play any role whatsoever.) Thus we may infer that idioms like the one I found in Kilivila are based on general physiological facts, and describe rather naturally our bodily reactions in certain situations of stress and emotion. If we agree that the localization of these feelings refers to symptoms we all have experienced physically, any notion of "culture specificness" becomes void.

There is still Malinowski's (1922:408-409) claim, however, that the Trobriand Islanders take their bellies as the place where they store their knowledge and inventory of magical formulae. And we documented the idiom as follows:

$\begin{array}{cc}\text { (6.1) ininaki lopogu } & \text { I keep it quiet } \\ & \text { I keep it to myself } \\ \text { literally: it keeps something for itself, my belly }\end{array}$

With this idiom we find the concept of the belly as a place for storing information again. I checked this notion with my informants in Tauwema in 1992, and I realized that Malinowski, the master, was right (as so often) once more-at least in general. All the expert magicians in Tauwema agreed that they store their magical formulae in their bellies-and some of them reacted to my question in exactly the same manner as did Malinowski's informant Kanukubusi: they struck their bellies several times! It may be easy to ridicule these men as "body-slappers" (Haviland 1987:15); catchy references like this one, however, disregard the Trobriand Islanders' explicit theory about magic. Although the role magic plays on the Trobriands is severely affected by cultural changes (Senft 1992) these days, even younger expert magicians still believe that it is in their bellies that they store the magical formulae that-as we would say-they "learnt by heart(!)" during their period of apprenticeship with their relatives who bestowed magical knowledge upon them as a (generally hereditary) gift.

Megwa esisu olopola lopogu, lopogu makala "store"

megwa e-sisu olopola lopo-gu lopo-gu makala store magic 3.Ps.-exist inside belly-my belly-my like store

"The magic is inside my belly, my belly is like a 'store" "-this is a typical answer I got from one of my informants. This answer also explains the 
various food taboos a magician has to regard before, during, and sometimes even after his performing of the magical rites: certain foods are tabooed because-according to the Trobrianders' indigenous belief system-they may spoil the magical formulae stored in the belly. Tokunupei explained to me what happens when he whispers his magical formulae:

Kidamwa amigai megwa va lopogu bila o nanogu e igau amigai megwa alivala meǵwa.

\begin{tabular}{lllllll} 
Kidamwa & \multicolumn{2}{l}{ a-migai } & megwa va & lopo-gu & bi-la & o \\
if & 1.Ps-whisper & magic from & belly-my & 3.Ps.Fut-go & to \\
Nano-gu & e & igau & amigai & megwa & a-livala & megwa \\
larynx-my & and then & 1.Ps.-whisper & magic & 1.Ps-speak & magic
\end{tabular}

"If I whisper magic, the magic(al formula) will go from the belly to my larynx and then I whisper magic, I speak (the) magic(al formula)."

This statement combines the two notions I would like to discuss in this subsection of the article. But before I discuss the Trobriand notion of nanola in connection with the question whether the "mind" resides somewhere in the "larynx," from the Trobriand point of view, I would like to finish the discussion of the "Trobriand belly" with some summarizing statements.

According to the Trobriand Islanders' indigenous belief system, the human belly functions as the store or, if you like, the "memory" for magical formulae and knowledge. This belief is the basis for a number of food taboos that ensure the safe and unspoilt storage of Trobriand magic. This belief is certainly culture specific; moreover, from the emic point of view it is also completely coherent. Malinowski described this idea correctly; however, at least according to my informants, he seems to have extended the idea somewhat by claiming "The memory, however, the store of formulae and traditions, learned by heart, resides deeper, in the belly..." (1922:408-409). My informants accept the belly as the store, or the "memory," for magical formulae only. They emphasize that all other aspects of (nonmagical) knowledge and tradition, such as songs, stories, legends, myths, and so on, are stored in the "head," that is, in the brain!

This argument may be contradicted by the idiom ininaki lopogu (I keep it quiet, I keep it to myself) that translates literally as "it keeps something for itself, my belly." This seems, however, to be a contradiction at first sight only: my informants told me that this idiom can be taken as a reminder for the hearer that the speaker will keep and guard the respective information as carefully and safely as she or he would do with magic.

Thus, I assume we can infer that it is only in connection with magic that we find verbal expressions that rely on a culture-specific belief system. Given the immense variety of forms of magic and magical rites documented in various cultures (see, e.g., Frazer 1978), however, this is not surprising at all.

But what about the Trobriand notion of "nanola" that does not only refer to "her/his larynx," but can also be translated as "her/his brain, mind, 
intelligence, idea, wants" ${ }^{10}$ Does this imply that for the Trobriand Islanders the mind really resides somewhere in the larynx?

For the Trobriand Islanders speech and the faculty of speech are inextricably intertwined with the larynx. If someone cannot speak, be it because she or he was born dumb or because she or he suffered brain damage or an injury that affected his or her capacity for speech, they say that the nanola is blocked inside.

olumolela itaboda nanola kidamwa tonagoa

$\begin{array}{lllll}\text { olumolela } & \text { i-taboda } & \text { nano-la } & \text { kidamwa } & \text { to-nagoa } \\ \text { inside } & \text { 3.Ps.-blocked } & \text { larynx-her/his } & \text { if } & \text { human-dumb }\end{array}$

"inside it is blocked, his/her larynx if (a person is) dumb."

Here we can infer that the larynx, which is responsible for phonation in speech, is somehow taken as a "pars pro toto" for the human faculty of speech. Its movements can be easily traced by touching the Adam's apple-native healers on the Trobriand Islands know about the basic physiology of this organ, and apply a mixture of herbs as a cure for temporary speech defects exactly at the spot where one can feel the larynx move in a healthy person. The Trobrianders are convinced that thinking takes place in the "head," that is, in the brain. Thoughts, however, have to be articulated, and this is done-according to their indigenous "theory of speech production" - by the larynx (as the active agent of the brain and mind) ${ }^{11}$ Hence they refer to the larynx as well as to the mind, to the brain, to intelligence, to ideas, and to wants with the same word. Ideas, thoughts, and wants originate in the mind, somewhere in the brain, the place of intelligence and cognitive capacities-with the exception of magic and magical knowledge which are taken, of course, as residing in the belly. But magical formulae as well as thoughts, ideas, and wants have to be articulated and verbalized to be effective, and this is also done by the larynx-according to the Trobriand theory of speech production. Thus we can conclude that although the vast majority of body-part idioms support the possibility of a "universal" organization in our conception of the nature of our bodies and of our inner states and feelings, a closer ethnolinguistic inspection of indigenous Trobriand ideas about the function of the belly and the larynx reveals that this does not exclude highly culture-specific theorizing with respect to the human faculty about which we all theorize more or less culture specifically_namely, the fascinating human faculty of speech.

\section{NOTES}

Acknowledgments. This article is based on 26 months of field research on the Trobriand Islands in 1982-83, 1989, 1992, 1993, and 1994. I want to thank the German Research Society and the Max Planck Society-especially the Cognitive Anthropology Research Group at the MPI for Psycholinguistics and its director Stephen C. Levinson-for their support in 
realizing my field research. Parts of this article were written while I was a guest at the Research School of Pacific Studies, Department of Linguistics, Australian National University in Canberra. I would like to thank Andy Pawley and his staff for their hospitality. I also want to thank the National and Provincial Governments in Papua New Guinea and the Institute for PNG Studies for their assistance with, and permission for, my research projects. I express my deepest gratitude to the people of the Trobriand Islands, especially to the inhabitants of Tauwema; I thank them for their hospitality, friendship, and patient cooperation. I also acknowledge insightful comments by Herb Clark, Eve Danziger, Paul Kay, Stephen C. Levinson, John Lucy, Dan Slobin, and Anna Wierzbicka.

1. For an excellent overview of anthropological literature on this topic see Lock 1993.

2. Note that Andersen points out that throughout her paper, "the focus is limited to external body parts, as opposed to internal organs" (1978:338).

3. Kilivila has one term (sikwekewe-PPIV) that refers to both "toenails" and "fingernails," thus constituting Andersen's sixth hierarchical level of human body-part partonomies: "Body-part partonomies rarely exceed five levels and never exceed six . . when there is a sixth level, it is usually composed of fingernail and/or toenail. . ." (Andersen 1978:348, emphasis in original).

4. This observation is not new, of course. It follows Immanuel Kant's classic statement in his pamphlet "Von dem ersten Grunde des Unterschiedes im Raume" (Kant 1968). See also Andersen 1978:342-343 and Clark 1973:33.

5. See, e.g., Coulmas 1982:20; Franklin and Franklin 1978:404-413; Haviland 1987:10; Keesing n.d.:22, 31; Kendon 1988:370, 401; Krupa 1988; Lichtenberk 1984:280-281; McElhanon 1975, 1977, 1982; Strathern 1994; Stolz 1991:7, 13-15.

6. If we exclude the cases where two body-part terms form a nominal compound that in itself is used to refer to a part of a body part, that is, where one body-part term is used as a metaphor for a part of another body part, we are left with one idiom only that goes together with the noun mata-PP IV.

7. In what follows I will exclude these special cases from the discussion; the numbers given refer to the numbers of the idioms listed in appendix B.

8. This is also with respect to we native speakers of Indo-European languages, of course. I am afraid, however, that I cannot discuss this latter point in the present paper. But see Lakoff and Johnson's (1980) pioneering work in this direction.

9. I have not provided German examples in this paper, but they can easily be provided-the analogies and parallels between them and the Kilivila idioms are really surprising! McElhanon (1982:50-53), however, also provides examples that emphasize how careful the linguist must be in comparing these idioms cross-culturally.

10. Here the critical reader may wonder why I have not glossed and translated nanola as "(her/his) larynx" in the idioms presented so far. This article, however, begins intentionally with a quote from Malinowski, and with his gloss "mind" for "nanola." The principle underlying my usage is simply to employ the more general gloss and to place the burden of explanation on instances of special or specific use of any term (that then requires another, more specific gloss). Anna Wierzbicka, for example, suggests that I should not translate nanola at all, but that I should gloss this expression as "(her/his) nano." I appreciate this idea, however; I think this is too easy a way out.

11. We find many metalinguistic expressions in Kilivila. The metalinguistic awareness of Kilivila speakers is quite sophisticated (see e.g., Senft 1991).

\section{REFERENEES EITED}

Andersen, Elaine S.

1978 Lexical Universals of Body-Part Terminology. In Universals of Human Language, vol. 3. Word Structure. J. H. Greenberg, ed. Pp 335-368. Stanford, CA: Stanford University Press. 
Bowden, John

1992 Behind the Preposition. Grammaticalization of Locatives in Oceanic Languages. Canberra: Australian National University.

Clark, Herbert

1973 Space, Time, Semantics, and the Child. In Cognitive Development and the Acquisition of Language. T. E. Moore, ed. Pp. 27-63. New York: Academic Press.

Conrad, Joseph 1988[1914] Chance: A Tale in Two Parts. Oxford: Oxford University Press.

Coulmas, Florian

1982 Ein Stein des Anstosses-Ausgewählte Probleme der Idiomatik. Studium Linguistik 13:17-36.

Franklin, Karl J., and Joice Franklin

1978 A Kewa Dictionary with Supplementary Grammatical and Anthropological Materials. Canberra: Australian National University.

Frazer, James George

1978[1922] The Golden Bough. A Study in Magic and Religion. Abridged edition. London: Macmillan.

Haviland, John

1987 Inner States and Body Metaphor. Department of Linguistics, Reed College, unpublished MS.

Heine, Bernd

1991 Conceptual Grammaticalization and Prediction. Institut für Afrikanistik, Cologne University, unpublished MS.

Heine, Bernd, Ulrike Claudi, and Friederike Hünnemeyer

1991 Grammaticalization: A Conceptual Framework. Chicago: University of Chicago Press.

Hockett, Charles F.

1958 A Course in Modern Linguistics. New York: Macmillan.

Kant, Immanuel

1968 [1768] Von dem ersten Grunde des Unterschiedes der Gegenden im Raume. In Kants Werke. Akademie Textausgabe, vol. 2. Vorkritische Schriften II, 1757-1777. Pp. 377-383. Berlin: Walter de Gruyter.

Keesing, Roger

N.d. Conventional Metaphors and Anthropological Metaphysics: The Problematic of Cultural Translation. Elaborated version of a paper presented for a conference on "Folk Models," Princeton, May 1983. Department of Anthropology, Research School of Pacific Studies, Australian National University Canberra, unpublished MS.

Kendon, Adam

1988 Sign Languages of Aboriginal Australia. Cambridge: Cambridge University Press.

Krupa, Viktor

1988 The Role of Metaphor in the Extension of Indonesian and Malay Vocabulary in

Comparison with Maori. Asian and African Studies 23:131-139.

Lakoff, George, and Mark Johnson

1980 Metaphors We Live By. Chicago: University of Chicago Press.

Lichtenberk, Frantisek

1984 A Grammar of Manam. Honolulu: University of Hawaii Press.

$\rightarrow$ Lock, Margaret

1993 Cultivating the Body: Anthropology and Epistemologies of Bodily Practice and

Knowledge. Annual Review of Anthropology 22:133-155.

Malinowski, Bronislaw

1922 Argonauts of the Western Pacific. London: Routledge and Kegan Paul.

1935 Coral Gardens and their Magic, 2 vols. London: Allen and Unwin. 
1968[1929] The Sexual Life of Savages in Northwestern Melanesia. London: Routledge and Kegan Paul.

McElhanon, Kenneth A.

1975 Idiomaticity in a Papuan (Non-Austronesian) Language. Kivung 8:103-144.

1977 Body Image Idioms in Irianese and Papua New Guinean Languages. Irian 6(3):3-27.

1982 On Teaching Idioms. In Gava-Studies in Austronesian Languages and Cultures

Dedicated to Hans Kähler. R. Carle, M. Heinschke, P. W. Pink, C. Rost, and K. Stadtlander, eds. Pp. 39-55. Berlin: Reimer.

Pawley, Andrew

1986 Lexicalization. In Languages and Linguistics: The Interdependence of Theory, Data, and Application. D. Tannen and J. A. Alatis, eds. Pp. 98-120. Washington, DC: Georgetown University Press.

Senft, Gunter

1986 Kilivila-The Language of the Trobriand Islanders. Berlin: Mouton de Gruyter.

1987 Nanam'sa Bwena-Gutes Denken. Eine ethnolinguistische Fallstudie über eine Dorfversammlung auf den Trobriand Inseln. Zeitschrift für Ethnologie 112:181-122.

1991 Prolegomena to the Pragmatics of "Situational-Intentional" Varieties in Kilivila Language. In Levels of Linguistic Adaptation: Selected Papers from the 1987 International Pragmatics Conference, vol. 2. J. Verschueren, ed. Pp. 235-248. Amsterdam: John Benjamins.

1992 As Time goes by ... Changes Observed in Trobriand Islanders' Culture and Language. In Culture Change, Language Change-Case Studies from Melanesia. T. Dutton, ed. Pp. 67-89. Canberra: Australian National University.

1993 A Grammaticalization Hypothesis on the Origin of Kilivila Classificatory Particles. Sprachtypologie und Universalienforschung 46:100-112.

1994 These "Procrustean Feelings". . - - Some of My Problems in Describing Kilivila. In Topics in Descriptive Austronesian Linguistics, Semaian 11. G. Reesink, ed. 86-105. Leiden, The Netherlands: University of Leiden.

Stolz, Thomas

1991 Grammatik aus dem (hohlen) Bauch. Anmerkungen zu einem Fallbeispiel von Grammatikalisierung des Körpers im klassischen Aztekisch. Department of Linguistics, Ruhr-University Bochum, unpublished MS.

Strathern, Andrew

1994 Keeping the Body in Mind. Social Anthropology 2:43-53.

Traugott, Elizabeth C., and Bernd Heine, eds.

1991 Approaches to Grammaticalization, 2 vols. Amsterdam: John Benjamins.

Tuggy, David

N.d. Scarecrow Nouns, Generalizations, an Cognitive Grammar. Department of Linguistics, University of Mexico, unpublished MS.

Weiner, Annette B.

1976 Women of Value, Men of Renown: New Perspectives in Trobriand Exchange. Austin: University of Texas Press.

1988 The Trobrianders of Papua New Guinea. New York: Holt, Rinehart and Winston. 


\section{APPESDIX A: KIUYLA BOOY-PART TERMS}

daba-PP IV
pwaneta-PP IV
mola
kunu-PP IV
unuunu
migi-PP IV
mata-PP IV
alapo-PP IV
pola
mitikululu-PP IV
kabulu-PP IV
kimwa-PP IV
mitikiki-PP IV
tega-PP IV
vado-PP IV
bilubilo-PP IV
gabula
kudu-PP IV
maye-PP IV
kasesala
kimla-PP IV
kego-PP IV
kayo-PP IV
dumwadomna
nano-PP IV
yagisa
vilava-PP IV
kuku-PP IV
vitako-PP IV
nunu-PP IV
matala nunu-PP IV
visiya-PP IV
lopo-PP IV
puso-PP IV
pwaso-PP IV
kapo'u-PP IV
sibuvaga

kuvali-PP IV

kaniva-PP IV

kepapa-PP IV head, forehead, brain

head, skull, bone

fontanelle (mola + PP II, indicating a degree of possession intermediate between intimate and more distant possession)

hair

body hair (+ PP II) (+ terms that refer to locks, thick, straight, matted hair, etc.)

face ( + terms that refer to a beautiful face, etc.)

eye (+ terms that refer to big, protruding, beautiful eyes, etc.)

eyebrow(s)

eyebrow(s) (+ PP II)

eyelash

nose

cheek

cheek-bone

ear (+ terms that refer to protruding ears, etc.)

mouth

lip (+ terms that refer to ugly, pinched lips, etc.)

chin, beard (+ PP II)

tooth, teeth

tongue

uvula (+ PP II)

jaw

neck

neck, throat

Adam's apple (+ PP III, indicating a more distant degree of possession)

larynx, mind, intelligence, idea

diaph ragm, midriff (+ PP III)

shoulder

chest, heart

chest

breast ( + terms to refer to small, flabby, round breasts, etc.)

nipple (the eye / tip of the breast)

rib

belly, windpipe, innards

navel, umbilical cord

navel, umbilical cord

back

back, backbone (+ PP II)

[Note that the expression "olakeda bunami" is also used to refer to the backbone; its literal meaning is "on the road of the coconut oil," that is, where the oil flows down when the body is oiled.]

waist

hip

side, flank 


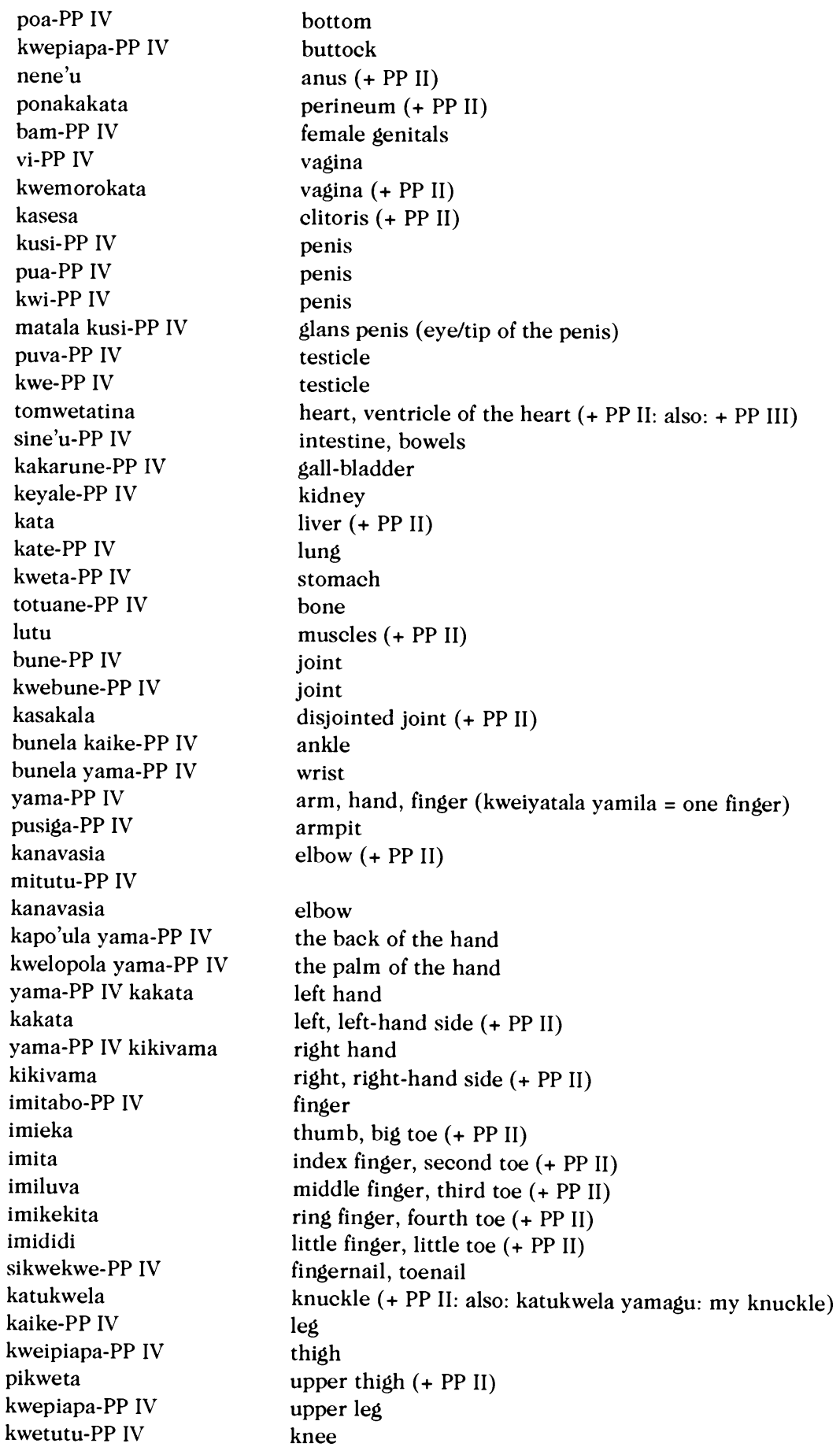




\section{$96 \bullet$ ETHOS}

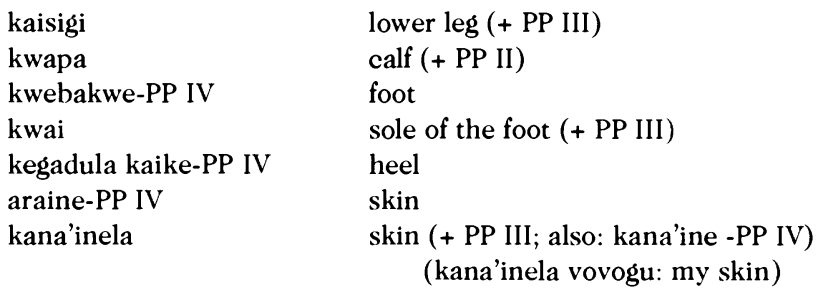

I would like to note here that one could subgroup these terms according to the degree of possession expressed by the three different forms of possessive pronouns that go with the terms listed above. Thus, one could argue that only the terms that go with the "PP-IV" series constitute the Kilivila body-part terms proper, while those terms that go with the "PP-II" and "PP III" series refer to body-part regions, hair, inner organs and more intimate parts of the body. This is speculation, however, and I could not find a convincing way to subcategorize those terms that are not formed with the "PP-IV" series.

For the sake of completeness I list here the second and third series of Kilivila possessive pronouns (which I abbreviate as "PP II" and "PP III" respectively):

PP II

$\begin{array}{lll}\text { 1.Ps.Sg. } & \text { agu } & \text { my } \\ \text { 2.Ps.Sg. } & \text { am } & \text { your } \\ \text { 3.Ps.Sg. } & \text { ala } & \text { her/his } \\ \text { Dual incl. } & \text { ada } & \text { our } \\ \text { Dual excl. } & \text { ama } & \text { our } \\ \text { 1.Ps.Pl.incl. } & \text { kadesi } & \text { our } \\ \text { 1.Ps.Pl.excl. } & \text { kamesi } & \text { our } \\ \text { 2.Ps.Pl. } & \text { ami } & \text { your } \\ \text { 3.Ps.Pl. } & \text { asi } & \text { their }\end{array}$

Thus, we have "ala mola"-_her/his fontanelle."

PP III

$\begin{array}{lll}\text { 1.Ps.Sg. } & \text { ula } & \text { my } \\ \text { 2.Ps.Sg. } & \mathrm{m} & \text { your } \\ \text { 3.Ps.Sg. } & \mathrm{la} & \text { her/his } \\ \text { Dual incl. } & \mathrm{da} & \text { our } \\ \text { Dual excl. } & \mathrm{ma} & \text { our } \\ \text { 1.Ps.Pl.incl. } & \mathrm{da}-\mathrm{si} & \text { our } \\ \text { 1.Ps.Pl.excl. } & \mathrm{ma}-\mathrm{si} & \text { our } \\ \text { 2.Ps.Pl. } & \mathrm{mi} & \text { your } \\ \text { 3.Ps.Pl. } & \mathrm{si} & \text { their }\end{array}$

Thus, we have "ula dumwadomna"-_my Adam's apple" and "dadumwadomnasi"_- "our Adam's apples." 
Kilivila-like many other Oceanic (and African) languages (see, e.g., Bowden 1992; Heine 1991; Heine et al. 1991; Traugott and Heine 1991)-also grammaticalizes some of its bodypart terms into locatives (For more details see Senft 1986:88-93, 1993, 1994). Thus, we find:

$\begin{array}{cl}\text { odabala } & \begin{array}{l}\text { on, on top of } \\ \text { (daba-PP IV-head, forehead, brain) } \\ \text { behind, back, behind him/her } \\ \text { (kapo'u-PP IV-back) } \\ \text { in, inside of } \\ \text { (lopo-PP IV-belly, windpipe, innards) } \\ \text { in front of, before, before him/her } \\ \text { (mata-PP IV-eye) } \\ \text { olopola } \\ \text { on, on top of, on the surface of, at the mouth (opening) of } \\ \text { (vado-PP IV-mouth) } \\ \text { on the left-hand side } \\ \text { (kakata-left, left-hand side) } \\ \text { on the right-hand side } \\ \text { (kikivama-right, right-hand side) } \\ \text { at the side of (a person only) } \\ \text { (kaniva-PP IV-hip) } \\ \text { near, close by, beside, at the side of } \\ \text { okikivama }\end{array} \\ \text { okanivala } & \text { kepapa-PP IV-side, flank) }\end{array}$

\section{APPENDIX B: SPEAKING IDIOMATEALY ABOUT THE BODY AND THE MHN IN KILUILA}

The following idioms are listed in general, unmarked word order. The word order pattern of Kilivila is rather free: changes occur and then generally imply foregrounding and thus emphasis on the constituent first mentioned (Senft 1986:107-112). Therefore, one must not speculate too much about culture-specific ways of expressing certain concepts on the basis of the morpheme-interlinear and literal translations given below.

(1) vovo-PP IV

ibisibasi vokuva vovogu

i-bisibasi vokuva vovo-gu

3.Ps.-wreathe entirely body-my

iǵwegwesi vovogu

i-gwegwesi

vovo-gu

(a) 3.Ps.-feel tired body-my

(b) 3. Ps-be fed up with sth. body-my

(1.3)

ikai'iki vovogu

i-kai'iki vovo-gu

3.Ps.-?? body-my body, upper part of the body

I am racked with pain

(a) I feel tired (staying in a foreign village [I feel homesick])

(b) I am fed up with sth. 
(1.4)

ikaikai vovog

I am lazy

i-kaikai vovo-gu

3.Ps-?? body-my

(1.5)

imama vovogu

I feel weak

i-mama vovo-gu

3.Ps.-get weak body-my

(1.6)

imwana vovogu

I am happy

i-mwana vovo-gu

3.Ps.?? body-my

(1.7)

itau vovogu

i-tau

vovo-gu

3.Ps.-find, finish body-my

(1.8)

itoki vovogu

i-toki

vovo-gu

3.Ps-stand, attend body-my

I feel overburdened

(1.9)

itutu vovogu

i-tutu

vovo-gu

3.Ps.-hammer, hit body-my

(1.10)

itutuvakau vovogu

i-tutuvakau

vovo-gu

3.Ps.-to hammer+?? body-my

I am relieved

(1.11)

vovogu yuviyavi

I am feverish

vovo-gu yuviyavi

body-my hot

(2) daba-PP IV

head, forehead, brain

(2.1)

dabagu gidageda

I have a headache

daba-gu gidageda

head-my pain

mtona dabasi tommota

m-to-na daba-si

this is a wise person

this-man-this head-their

tommota

people

(2.3)

ibulumse'u dabala

$\mathrm{s} /$ he lost his/her head, $\mathrm{s} /$ he is confused

i-bulumse'u daba-la

3.Ps-smoke head-his/her 
(2.4)

pe'ula dabala

pe'ula daba-la

strong head-his/her

(2.5)

kasai dabala

kasai daba-la

hard head-his/her

(2.6)

dabala yuviyavi

daba-la yuviyavi

head-his/her hot

(3) mata-PP IV

(3.1)

matala ibiriuya

mata-la i-biriuya

eye-her/his 3.Ps-distort, twist

matala nunum

mata-la nunu-m

tip/eye-her/his breast-your

(3.3)

matala kusila

mata-la kusi-la

tip/eye-his penis-his

(4) tega-PP IV

(4.1)

kasai tegila

kasai

hard, tough, difficult, onerous

(5) vado-PP IV

iudu vadola

i-udu vado-la

3.Ps-?? mouth-her/his

(6) lopo-PP IV

(6.1)

ininaki lopogu

i-ninaki

3.Ps-keep something for oneself a confident person

a stupid person

$\mathrm{s} / \mathrm{he}$ is feverish

eye

$\mathrm{s} /$ he is unconscious

$s /$ he is fainting

his/her eyes are distorted.

your nipple

his glans

ear

$\mathrm{s} /$ he is feigning deafness, being angry

tegi-la

ear-her/his

mouth

s/he cannot keep his/her mouth shut $\mathrm{s} /$ he is a hypocrite

belly, windpipe, innards

lopo-gu

I keep it quiet/to myself

belly-my 
(6.2)

ikapisi lopola

i-kapisi lopo-la

3.Ps-feel pity belly-his/her s/he is sorry, she mourns

s/he feels pity with someone

Besides the idioms with body-part terms the Kilivila lexicon also displays a number of idioms that go together with the Trobriand Islanders' concept of "nano-PP IV," which refers to the "larynx" but which can also be translated as "mind" or as "intelligence," and in some contexts also as "idea" or "wants." Like most of the body-part terms presented above, this noun obligatorily needs a possessive pronominal suffix indicating an intimate degree of possession. (I abbreviate this suffix as "PP IV".) The suffixation of the possessive pronominal affixes to the noun "nano-PP IV" (mind) follows the same paradigm as the one given above in connection with the noun "vovo-PP IV" (body). Again, in these idioms we most often observe the combination of the noun "nano-PP IV" with verbal expressions in the third person singular or plural (some of these verbal expressions are only produced in the documented idiomatic usage; thus, I could not find out the meaning of the verbal expression isolated from the noun "nano-PP IV"). Following is a list of the idiomatic expressions involving "nano-PP IV" which I was able to document. In addition to these, there is a noun nagoa (stupidity), an adjective -nagoa (stupid, incalculable, out of humor, having a defect of speech, dumb, deaf) and a verbal expression -nagoa- and its variant -nagova(to be stupid, to be crazy); however, I cannot decide whether these expressions are (etymologically or morphologically) related to the noun nano-PP $I V$.

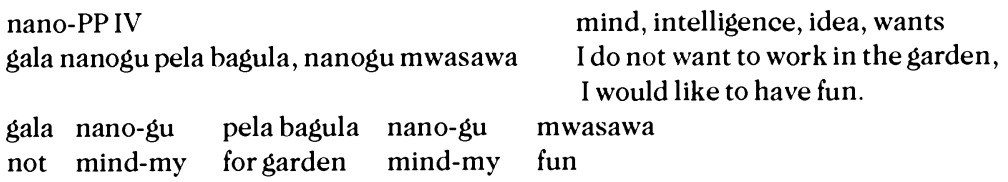

(1)

ida'ila nanom

$$
\text { i-da'ila }
$$

(a) 3.Ps.-change

(b) 3.Ps.-remember

(2)

ikaikai nanosi

i-kaikai nano-si

3.Ps-?? mind-their

(see?: kaikaila "lightning") (a) it changes, your mind

(b) it remembers, your mind

\section{nano-m}

mind-your

mind-your

(3)

bikalisau nanom

it irritates them

\section{bi-kalisau}

(a) 3.Ps.Fut-to be outstanding

(b) 3.Ps.Fut-to steal

(4)

ikanta'ila nanodasi

i-kanta'ila

nano-dasi

3.Ps.-persuade, convince, mind-our to turn one's head (a) it will charm you

(b) you will steal sth

nano-m

mind-your

mind your

it convinces us

it persuades us 
(5)

ikamituli nanogu

i-kamituli

I admit (reveal, report)

3.Ps.-admit, report, reveal

nano-gu

mind-my

(6)

ikatotila nanom

i-katotila nano-m

you are determined (to do something)

3.Ps.-promise mind-your

(7)

ikavisi nanosi

i-kavisi

they are fascinated

3.Ps-fascinate, to be fascinated

nano-si

mind-their

(8)

ikitu nanola

i-kitu nano-la

s/he withdraws within her/himself, $\mathrm{s} / \mathrm{he}$ is afraid

3.Ps.-withdraw mind-her/his

(9)

iluvai nanogu

i-luvai

nano-gu

I remember

3.Ps.-remember

mind-my

(10)

bimanum nanomi

bi-manum nano-mi

you won't be angry (your minds will be soft)

3.Ps.Fut-gentle mind-your

(11)

imwamwasila nanogu

i-mwamwasila

I am of good cheer, I am in good humor

3.Ps.-to be in a good mood mind-my

(12)

imwau nanogu

I am sad

i-mwau nano-gu

(my mind is heavy)

3.Ps.-?? mind-my

(see: mwau "grief"; (-)mau "heavy, hard")

gala bimau nanom

don't worry

gala bi-mau nano-m

not 3.Ps.Fut-heavy mind-your

(14)

imimi nanogu

(a) I dream

(b) I make magic

i-mimi nano-gu
(a) 3.Ps-dream
mind-my
(b) 3.Ps-make magic
mind-my 
(15)

\begin{tabular}{ll}
$\begin{array}{l}\text { ipani nanosi } \\
\text { i-pani }\end{array}$ & \multicolumn{1}{c}{$\begin{array}{c}\text { it confuses them } \\
\text { (it mixes them up) }\end{array}$} \\
\begin{tabular}{ll} 
3.Ps.-confuse & mind-their \\
ipolu nanom & \\
$\begin{array}{l}\text { i-polu } \\
\text { 3.Ps.-boil, worry, to be jealous }\end{array}$ & \multicolumn{1}{c}{ it makes you jealous } \\
mind-your
\end{tabular}
\end{tabular}

isavali nanom

i-savali nano-m

3.Ps.-try mind-your

you think it over

(18)

isim nanogu

i-sim nano-gu

3.Ps-sting, hurt mind-my

I am conscious of (something)

(19)

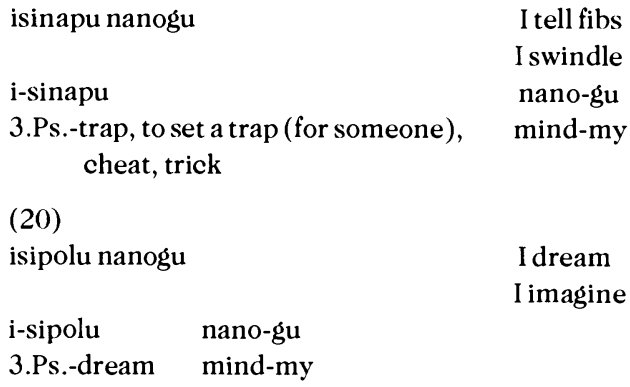

(21)

isivili nanodasi

it changes our minds

it converts us,

it turns us away (from someone)

i-sivili nano-dasi

3.Ps.-?? mind-our

(see: -sivila- "to turn round")

(22)

isugwa nanogu

I am overindulgent

it is very sweet and tasty

i-sugwa nano-gu

3.Ps.-?? mind-my

(23)

itaboda nanom

you are blockheaded

you are stultified

i-taboda nano-m

3.Ps.-block mind-your

(see: taboda "wall, door") 
(24)

itagwala nanogu

i-tagwala

nano-gu

3.Ps-agree, accept mind-my

(25)

itaki nanola

i-taki nano-la

3.Ps-cut mind-his/her

(26)

itamwau nanogu

i-tamwau nano-gu

3.Ps.-lose mind-my

(27)

itavilisi nanosi

i-tavili-si

nano-si

3.Ps.-turn-Pl

mind-their

(28)

iteya nanom

i-teya nano-m

3.Ps.-cut mind-your

and

ateya nanola

a-teya nano-la

1.Ps.-cut mind-her/his

(29)

itutu nanosi

i-tutu nano-si

3.Ps.-hammer, hit mind-their

and

itutuvakau nanosi

i-tutuvakau nano-si

3.Ps.-?? mind-their

(see: -vaki- "to hammer,"

-tutu- "to hammer")

(30)

ivagi nanogu

i-vagi nano-gu

3.Ps.-make, do mind-my

(31)

ivakavili nanom

i-vakavali

3.Ps.- to turn (something and continue doing something)
I agree

$\mathrm{s} /$ he is obsessed

\section{I forgot it}

it slipped my memory

they reconsider it

it confuses you

it "cuts" your mind

I change her/his mind

I turn her/his mind,

I charm her/him

they are impressed

(it "hammers" their minds)

they are very much impressed

it influences me

it turns your mind against something/someone nano-m

mind-your 
(32)

$\begin{array}{ll}\begin{array}{l}\text { iweya nanola } \\ \text { i-weya }\end{array} & \begin{array}{c}\text { s/he remembers (something) } \\ \text { nano-la }\end{array} \\ \begin{array}{ll}\text { 3.Ps.-float, bring (something to someone) } & \text { mind-his/her }\end{array} & \begin{array}{l}\text { mind } \\ \text { (33) }\end{array}\end{array}$

(33)

iyelu nanogu

i-yelu nano-gu

3.Ps.-think of, remember mind-my

(34)

iyogagi nanola

$\begin{array}{ll}\text { i-yogagi } & \text { nano-la } \\ \text { 3.Ps.-spoil, ill-treat } & \text { mind-her/his }\end{array}$

(35)

iyokwaisi nanodasi

i-yokwai-si nano-dasi

3.Ps.-??-Pl. mind-our

(36)

bala nanogu

ba-la

1.Ps.Fut-go (away from speaker)

(37)

nanogu gaga

nano-gu gaga

mind-my bad, wrong

(38)

mtona gala nona

m-to-na gala nona

this-man-this not mind

\section{I long for it}

I am inspired with it it upsets her/him

(it spoils her/him)

we rack our brains (over something)

\author{
I will have an idea \\ nano-gu \\ mind-my
}

I am in a bad mood

he is senseless

he is stupid (motionless, witless, idiotic) 